\title{
New rubrolides from the marine-derived fungus Aspergillus terreus OUCMDZ-1925
}

\author{
Tonghan Zhu ${ }^{1,3}$, Zhengqian Chen ${ }^{1,3}$, Peipei Liu ${ }^{1}$, Yi Wang ${ }^{1}$, Zhihong $\mathrm{Xin}^{2}$ and Weiming Zhu ${ }^{1}$ \\ Two new rubrolides, rubrolides $\mathrm{R}(1)$ and $\mathrm{S}(2)$, were isolated from the fermentation broth of the marine-derived fungus \\ Aspergillus terreus OUCMDZ-1925. Their structures were elucidated on the basis of spectroscopic analysis and X-ray single \\ crystal diffraction. Compound 1 showed comparable or superior antioxidation against 2,2'-azino-di(3-ethylbenzthiazoline-6- \\ sulfonic acid) (ABTS) radicals to those of trolox and ascorbic acid with an $\mathrm{IC}_{50}$ value of $1.33 \mathrm{~mm}$. Compound 2 showed \\ comparable or superior anti-influenza $A(H 1 N 1)$ virus activity to that of ribavirin with an $\mathrm{IC}_{50}$ value of $87.1 \mu \mathrm{M}$. Both \\ compounds 1 and 2 showed weak cytotoxicity against the $\mathrm{K} 562$ cell line with $\mathrm{IC}_{50}$ values of 12.8 and $10.9 \mu \mathrm{m}$, respectively. \\ The Journal of Antibiotics (2014) 67, 315-318; doi:10.1038/ja.2013.135; published online 11 December 2013
}

Keywords: anti-H1N1 virus; antioxidation; Aspergillus terreus; cytotoxicity; marine-derived fungus; rubrolides

\section{INTRODUCTION}

Marine-derived fungi have long been recognized as a potential source of structurally novel and pharmacologically active metabolites. ${ }^{1-3}$ Many bioactive compounds including polyketides, terpenes, steroids and peptides have been isolated from cultured fungi. ${ }^{2}$ Rubrolides comprising a central furanone ring substituted at C-3 and C-4 with two 4-hydroxyphenyl moieties, ${ }^{4} \mathrm{~A}-\mathrm{Q}$, for example, were obtained from marine tunicate. ${ }^{5-9}$ This type of compounds posses antibacterial activity, ${ }^{5,6,9}$ cytotoxicity, ${ }^{7}$ inhibition of aldose reductase, ${ }^{10,11}$ antiinflammatory activity $^{8}$ and selective inhibition of protein phosphatases 1 and $2 \mathrm{~A}^{5}$ As part of our ongoing research on bioactive compounds from marine fungal origin, ${ }^{12-17}$ marinederived Aspergillus terreus OUCMDZ-1925 was isolated from the viscera of the barracuda (Chelon haematocheilus) grown in the Yellow River estuary. The Yellow River delta formed from the convergence of the Yellow River mouth and the Bohai Sea possesses a unique wetland environment different from both the sea and the land. The solid state fermented products of A. terreus OUCMDZ1925 showed antibacterial effects on Bacillus subtilis, from which four butyrolactones (I-IV) and methyl 2,4-dihydroxy-3,5,6trimethylbenzoate with antibacterial effects on Staphylococcus aureus, Enterobacter aerogenes, Bacillus subtilis and Escherichia coli were identified. ${ }^{12}$ To further enrich the chemical diversity of this fungus, A. terreus OUCMDZ-1925 was refermented in a liquid medium and the ethyl acetate (EtOAc) extract of the products showed 53\% inhibition of the growth of P388 cells at a concentration of $100 \mu \mathrm{g} \mathrm{ml}^{-1}$. Chemical investigation resulted in the isolation of two new rubrolides that we named rubrolides $\mathrm{R}$ (1) and $\mathrm{S}$ (2).
Rubrolide R (1) showed inferior antioxidation against 1,1-diphenyl-2picrylhydrazyl (DPPH) radical to that of ascorbic acid and comparable or superior antioxidation against 2,2'-azino-di(3ethylbenzthiazoline-6-sulfonic acid) (ABTS) radical to those of ascorbic acid and trolox with $\mathrm{IC}_{50}$ values of $43.4 \mu \mathrm{M}$ and $1.33 \mathrm{~mm}$, respectively. Rubrolide S (2) exhibited comparable or superior antivirus activity against influenza $A(\mathrm{H} 1 \mathrm{~N} 1)$ virus to that of ribavirin with an $\mathrm{IC}_{50}$ value of $87.1 \mu \mathrm{M}$. Both compounds 1 and 2 showed weak cytotoxic effects on the K562 cell line with $\mathrm{IC}_{50}$ values of 12.8 and $10.9 \mu \mathrm{M}$, respectively.

\section{RESULTS}

Physico-chemical properties

Rubrolide $R$ (1). Yellow amorphous powder and colorless triclinic crystal after cultured in acetone and the atmosphere of benzene by solvent diffusion method; mp 202-203 ${ }^{\circ} \mathrm{C}$; HRESIMS m/z 349.1432 $[\mathrm{M}+\mathrm{H}]^{+}\left(\right.$calcd for $\left.\mathrm{C}_{22} \mathrm{H}_{21} \mathrm{O}_{4}, 349.1434\right) ; \mathrm{UV}(\mathrm{MeOH}) \lambda_{\max }(\log \varepsilon)$ 203 (4.41), 250 (4.03), 378 (4.24) nm; IR $v_{\max }(\mathrm{KBr}) 3322,2960$, 2923, 2853, 1730, 1701, 1540, 1508, 1457, 1433, 1261, 1091, 1032, $803 \mathrm{~cm}^{-1} ;{ }^{1} \mathrm{H}$ and ${ }^{13} \mathrm{C}$ NMR (see Table 1 ).

Rubrolide S (2). Yellow solid; HRESIMS $m / z 349.1430[\mathrm{M}+\mathrm{H}]^{+}$ (calcd for $\left.\mathrm{C}_{22} \mathrm{H}_{21} \mathrm{O}_{4}, 349.1434\right)$; UV (MeOH) $\lambda_{\max }(\log \varepsilon) 203$ (4.39), $252(4.01), 376(4.22) \mathrm{nm}$; IR $v_{\max }(\mathrm{KBr}) 3330,2972,2928,2852$, $1719,1608,1571,1495,1345,1267,1236,1174,1121,824 \mathrm{~cm}^{-1} ;{ }^{1} \mathrm{H}$ and ${ }^{13} \mathrm{C}$ NMR (see Table 1$)$.

\footnotetext{
${ }^{1}$ Key Laboratory of Marine Drugs, Ministry of Education of China, School of Medicine and Pharmacy, Ocean University of China, Qingdao, China and ${ }^{2}$ Key Laboratory of Food Processing and Quality Control, College of Food Science and Technology, Nanjing Agricultural University, Nanjing, China

${ }^{3}$ These authors contributed equally to this work.

Correspondence: Professor W Zhu, Key Laboratory of Marine Drugs, Ministry of Education of China, School of Medicine and Pharmacy, Ocean University of China, Qingdao, Shandong 266003, China.

E-mail: weimingzhu@ouc.edu.cn

Received 21 August 2013; revised 7 November 2013; accepted 15 November 2013; published online 11 December 2013
} 
Table $1{ }^{1} \mathrm{H}-(600 \mathrm{MHz})$ and ${ }^{13} \mathrm{C}-(150 \mathrm{MHz}) \mathrm{NMR}$ data for 1 and 2 in DMSO- $d_{6}$

\begin{tabular}{|c|c|c|c|c|}
\hline \multirow[b]{2}{*}{ Position } & \multicolumn{2}{|r|}{1} & \multicolumn{2}{|r|}{2} \\
\hline & $\delta_{\mathrm{C}}$ & $\delta_{\mathrm{H}}(\mathrm{J}$ in $\mathrm{Hz})$ & $\delta_{\mathrm{C}}$ & $\delta_{\mathrm{H}}(\mathrm{J}$ in $\mathrm{Hz})$ \\
\hline 1 & $168.8, \mathrm{C}_{\mathrm{q}}$ & & $168.8, \mathrm{C}_{\mathrm{q}}$ & \\
\hline 2 & 110.7, CH & $6.34, \mathrm{~s}$ & $110.9, \mathrm{CH}$ & $6.37, \mathrm{~s}$ \\
\hline 3 & $158.2, \mathrm{C}_{\mathrm{q}}$ & & $158.2, \mathrm{C}_{\mathrm{q}}$ & \\
\hline 4 & $145.3, \mathrm{C}_{\mathrm{q}}$ & & $145.7, \mathrm{C}_{\mathrm{q}}$ & \\
\hline 5 & $113.9, \mathrm{CH}$ & $6.27, \mathrm{~s}$ & $113.4, \mathrm{CH}$ & $6.31, \mathrm{~s}$ \\
\hline $1^{\prime}$ & $124.3, \mathrm{C}_{\mathrm{q}}$ & & $124.9, \mathrm{C}_{\mathrm{q}}$ & \\
\hline $2^{\prime}$ & $132.5, \mathrm{CH}$ & $7.56, \mathrm{~d}(2.2)$ & $132.5, \mathrm{CH}$ & $7.57, \mathrm{~d}(2.2)$ \\
\hline $3^{\prime}$ & $128.2, \mathrm{C}_{\mathrm{q}}$ & & $121.4, \mathrm{C}_{\mathrm{q}}$ & \\
\hline $4^{\prime}$ & 156.7, $\mathrm{C}_{\mathrm{q}}$ & & $154.9, \mathrm{C}_{\mathrm{q}}$ & \\
\hline $5^{\prime}$ & $115.4, \mathrm{CH}$ & $6.86, \mathrm{~d}(8.8)$ & $117.5, \mathrm{CH}$ & $6.78, \mathrm{~d}(8.2)$ \\
\hline $6^{\prime}$ & $130.1, \mathrm{CH}$ & $7.53, \mathrm{dd}(8.8,2.2)$ & $130.1, \mathrm{CH}$ & $7.58, \mathrm{dd}(8.2,2.2)$ \\
\hline $7^{\prime}$ & $28.0, \mathrm{CH}_{2}$ & $3.22, \mathrm{~d}(7.7)$ & $21.8, \mathrm{CH}_{2}$ & $2.75, \mathrm{t}(6.6)$ \\
\hline $8^{\prime}$ & $122.5, \mathrm{CH}$ & $5.26, \mathrm{t}(7.7)$ & $32.0, \mathrm{CH}_{2}$ & $1.78, \mathrm{t}(6.6)$ \\
\hline $9^{\prime}$ & $131.9, \mathrm{C}_{\mathrm{q}}$ & & $75.1, \mathrm{C}_{\mathrm{q}}$ & \\
\hline $10^{\prime}$ & $25.6, \mathrm{CH}_{3}$ & $1.69, \mathrm{~s}$ & 26.7, $\mathrm{CH}_{3}$ & $1.29, \mathrm{~s}$ \\
\hline $11^{\prime}$ & $17.8, \mathrm{CH}_{3}$ & $1.68, \mathrm{~s}$ & $26.7, \mathrm{CH}_{3}$ & $1.29, \mathrm{~s}$ \\
\hline $1^{\prime \prime}$ & $120.8, \mathrm{C}_{\mathrm{q}}$ & & $120.5, \mathrm{C}_{\mathrm{q}}$ & \\
\hline $2^{\prime \prime}\left(6^{\prime \prime}\right)$ & $130.5, \mathrm{CH}$ & $7.48, \mathrm{~d}(7.7)$ & $130.5, \mathrm{CH}$ & $7.48, \mathrm{~d}(8.8)$ \\
\hline $3^{\prime \prime}\left(5^{\prime \prime}\right)$ & 116.0, CH & $6.93, \mathrm{~d}(7.7)$ & $116.1, \mathrm{CH}$ & $6.92, \mathrm{~d}(8.8)$ \\
\hline $4^{\prime \prime}$ & $159.8, \mathrm{C}_{\mathrm{q}}$ & & $160.2, \mathrm{C}_{\mathrm{q}}$ & \\
\hline
\end{tabular}

\section{Biological activity}

The antiviral activity against $\mathrm{H} 1 \mathrm{~N} 1$ virus of compounds $\mathbf{1}$ and $\mathbf{2}$ was evaluated by the CPE inhibition assay. ${ }^{18,19}$ The observed $\mathrm{IC}_{50}$ values of 1,2 and ribavirin (a positive control) against $\mathrm{H} 1 \mathrm{~N} 1$ virus were 221.6, 87.1 and $118.8 \mu \mathrm{M}$, respectively. Compound 2 showed comparable or superior anti-H1N1 activity to that of ribavirin.

The cytotoxicities of the two compounds against K562, A549 and HL-60, and Hela and HCT-116 cell lines were evaluated by the MTT method $^{20}$ and SRB method, ${ }^{21}$ respectively. The results showed that compounds 1 and 2 are cytotoxic on the K562 cell line with $\mathrm{IC}_{50}$ values of 12.8 and $10.9 \mu \mathrm{M}$, respectively, as they are not active against the A549, HL-60, Hela and HCT-116 cell lines ( IC $\left._{50}>30 \mu \mathrm{M}\right)$. The $\mathrm{IC}_{50}$ values of adriamycin (a positive control) against K562, A549, HL-60, Hela and HCT-116 cell lines were $0.64,0.16,0.65,0.60$ and $0.21 \mu \mathrm{M}$, respectively.

The anti-oxidative activities of $\mathbf{1}$ and $\mathbf{2}$ against $\mathrm{DPPH}^{22-24}$ and ABTS $^{25-27}$ radicals were also assayed. Compared with ascorbic acid and trolox (two positive controls), compound 1 displayed weak DPPH radical-scavenging activity and comparable or superior ABTS radical-scavenging activity with $\mathrm{IC}_{50}$ values of $43.4 \mu \mathrm{M}$ and $1.33 \mathrm{~mm}$, respectively, when compound 2 was not active $\left(\mathrm{IC}_{50}>100 \mu \mathrm{M}\right.$ and $50 \mathrm{~mm}$, respectively). The $\mathrm{IC}_{50}$ values of ascorbic acid against DPPH and ABTS radicals and trolox against ABTS radical were $1.7 \mu \mathrm{M}$, $2.85 \mathrm{~mm}$ and $2.04 \mathrm{~mm}$, respectively. The results showed that phenolic$\mathrm{OH}$ in the benzal nucleus has a key role in antioxidation of 1 against $\mathrm{DPPH}$ and ABTS radicals.

\section{Structure determination}

Compound 1 was assigned the molecular formula of $\mathrm{C}_{22} \mathrm{H}_{20} \mathrm{O}_{4}$ based on the HRESIMS peak at $\mathrm{m} / z 349.1432[\mathrm{M}+\mathrm{H}]^{+}$. The IR spectrum indicated the existence of hydroxyls $\left(3322 \mathrm{~cm}^{-1}\right)$, an ester or lactone carbonyl $\left(1730 \mathrm{~cm}^{-1}\right)$ and aromatic nucleus $\left(1540 \mathrm{~cm}^{-1}\right)$. The ${ }^{1} \mathrm{H}$
NMR spectrum showed an $\mathrm{A}_{2} \mathrm{~B}_{2}$ system at $\delta_{\mathrm{H}} 7.48(\mathrm{~d}, 2 \mathrm{H}, J=7.7 \mathrm{~Hz})$ and $6.93(\mathrm{~d}, 2 \mathrm{H}, J=7.7 \mathrm{~Hz})$, corresponding to a 1,4-disubstituted phenyl ring. The ${ }^{1} \mathrm{H}$ NMR signals of the ABX system at $\delta_{\mathrm{H}} 7.56(\mathrm{~d}$, $1 \mathrm{H}, J=2.2 \mathrm{~Hz}), 6.86(\mathrm{~d}, 1 \mathrm{H}, J=8.8 \mathrm{~Hz})$ and $7.53(\mathrm{dd}, 1 \mathrm{H}, J=8.8 \mathrm{~Hz}$, $2.2 \mathrm{~Hz}$ ) indicated an additional 1,2,4-trisubstituted phenyl ring. These data suggested 1 as a rubrolide. ${ }^{28}$ The ${ }^{1} \mathrm{H}$ and ${ }^{13} \mathrm{C}$ NMR spectra (Table 1, Supplementary Figures S1-S4) of 1 were similar to those of rubrolide $\mathrm{E}^{28}$ with the exception that an aromatic methine signal $\left(\delta_{\mathrm{C} / \mathrm{H}} 117.6 / 6.84\right)$ was replaced by an aromatic quaternary carbon signal $\left(\delta_{\mathrm{C}} 128.2\right)$ and additional prenyl signals that is two methyl $\left(\delta_{\mathrm{C} / \mathrm{H}} 25.6 / 1.69\right.$ and $\left.17.8 / 1.68\right)$, a methylene $\left(\delta_{\mathrm{C} / \mathrm{H}} 28.0 / 3.22\right)$, an olefinic methine $\left(\delta_{\mathrm{C} / \mathrm{H}} 122.5 / 5.26\right)$ and an olefinic quaternary carbon $\left(\delta_{\mathrm{C}} 131.9\right)$, indicating 1 as a $3^{\prime}$-prenylated derivative of rubrolide $\mathrm{E}$. This deduction was confirmed by COSY correlation of $\mathrm{H}-7^{\prime}\left(\delta_{\mathrm{H}} 3.22\right)$ to $\mathrm{H}-8^{\prime}\left(\delta_{\mathrm{H}}\right.$ 5.26) (Supplementary Figure S5) and key $\mathrm{HMBC}$ correlations of $\mathrm{H}-11^{\prime}$ to $\mathrm{C}-8^{\prime} / \mathrm{C}-9^{\prime} / \mathrm{C}-10^{\prime}$ and $\mathrm{H}-7^{\prime}$ to $\mathrm{C}-3^{\prime} / \mathrm{C}-4^{\prime}$ (Figure 1 and Supplementary Figure S6). The single-crystal X-ray diffraction analysis further confirmed the structure (Figure 2), and the $Z$-configuration of $\Delta^{4(5)}$ double bond was also resolved. Thus, the structure of rubrolide $\mathrm{R}(\mathbf{1})$ was elucidated to be (Z)-5-(4-hydroxy-3prenylbenzal)-4-(4-hydroxyphenyl) furan-2-one.

Compound 2 was obtained as a yellow solid with the same molecular formula of $\mathrm{C}_{22} \mathrm{H}_{20} \mathrm{O}_{4}$ based on the HRESIMS peak at $\mathrm{m} / \mathrm{z} 349.1430[\mathrm{M}+\mathrm{H}]^{+}$, indicating an isomer of 1 . The IR spectrum showed the presence of phenolic $\mathrm{OHs}$ at $3330 \mathrm{~cm}^{-1}$, ester/lactone carbonyls peaks at $1719 \mathrm{~cm}^{-1}$ and aromatic rings at $1608 \mathrm{~cm}^{-1}$. Except for a prenylated phenyl nucleus moiety, its ${ }^{1} \mathrm{H}$ and ${ }^{13} \mathrm{C} \mathrm{NMR}$ data (Table 1, Supplementary Figures S7-S10) were very similar to those of 1 , suggesting the same $4(Z)$-benzal-3-phenyl- $\gamma$-butyrolactone skeleton with 1 that was confirmed by an NOE correlation between $\mathrm{H}-5\left(\delta_{\mathrm{H}} 6.31\right)$ and $\mathrm{H}-2^{\prime \prime}\left(6^{\prime \prime}\right)\left(\delta_{\mathrm{H}} 7.48\right)$ (Figure 1 and Supplementary Figure S13). Careful NMR comparison between 1 and 2 revealed that a sp3 methylene signal $\left(\delta_{\mathrm{C} / \mathrm{H}} 32.0 / 1.78\right)$ and an oxygenated quaternary carbon signal $\left(\delta_{\mathrm{C}} 75.1\right)$ in 2 replaced the corresponding trisubstituted ethylene signals $\left(\delta_{\mathrm{C} / \mathrm{H}} 122.5 / 5.26, \delta_{\mathrm{C}} 131.9\right)$ in 1 , indicating that an intramolecular electrophilic addition of phenolic-OH with the trisubstituted ethylene of 1 occurs to form a dihydropyran ring fused to the trisubstituted benzene ring of 2 . This deduction was further supported by the key COSY correlation between $\mathrm{H}-\mathrm{7}^{\prime}$ and $\mathrm{H}-\mathrm{8}^{\prime}$ (Supplementary Figure S11) and $\mathrm{HMBC}$ correlations of $\mathrm{H}-7^{\prime}$ to $\mathrm{C}-2^{\prime} / \mathrm{C}-3^{\prime} / \mathrm{C}-4^{\prime}$ and of $\mathrm{H}-8^{\prime}$ to $\mathrm{C}-9^{\prime} / \mathrm{C}-10^{\prime} / \mathrm{C}-11^{\prime}$ (Supplementary Figure S12), as well as the upfield shifts of $\mathrm{C}-3^{\prime} / \mathrm{C}-4^{\prime} / \mathrm{C}-7^{\prime}$ and the downfield shifts of $\mathrm{C}-5^{\prime} / \mathrm{C}-10^{\prime} / \mathrm{C}-11^{\prime}$. Therefore, the structure of rubrolide S (2) was identified as $(Z)-5-((2,2$-dimethylchroman-6-yl) methylene)-4-(4-hydroxyphenyl)furan-2-one.

\section{METHODS}

\section{General experimental procedures}

UV spectra were measured on a Unico 2802 PCS spectrophotometer. IR spectra were recorded on a Nicolet Nexus 470 spectrophotometer as $\mathrm{KBr}$ disks. ${ }^{1} \mathrm{H},{ }^{13} \mathrm{C} \mathrm{NMR}, \mathrm{DEPT}$ and $2 \mathrm{D}-\mathrm{NMR}$ spectra were recorded on a JEOL JNM-ECP 600 spectrometer using TMS as the internal standard and chemical shifts were recorded as $\delta$ values. NOESY spectra were obtained on a Bruker Avance 600 spectrometer. The HRESIMS measurements were taken on a Q-TOF ULTIMA GLOBAL GAA076 LC mass spectrometer. The semi-preparative HPLC was performed using an ODS column (YMC-pak ODS-A, $10 \times 250 \mathrm{~mm}, 5 \mu \mathrm{m}, 4.0 \mathrm{ml} \mathrm{min}^{-1}$ ). TLC and column chromatography were performed on plates precoated with silica gel $\mathrm{GF}_{254}$ (10-40 $\mu \mathrm{m}$, Qingdao Marine Chemical Factory, Qingdao, China) and over Sephadex LH-20 (Amersham Biosciences, Uppsala, Sweden), respectively. Vacuum-liquid chromatography (VLC) utilized silica gel (200-300 mesh, Qingdao Marine Chemical Factory). Sea salt used was made by 


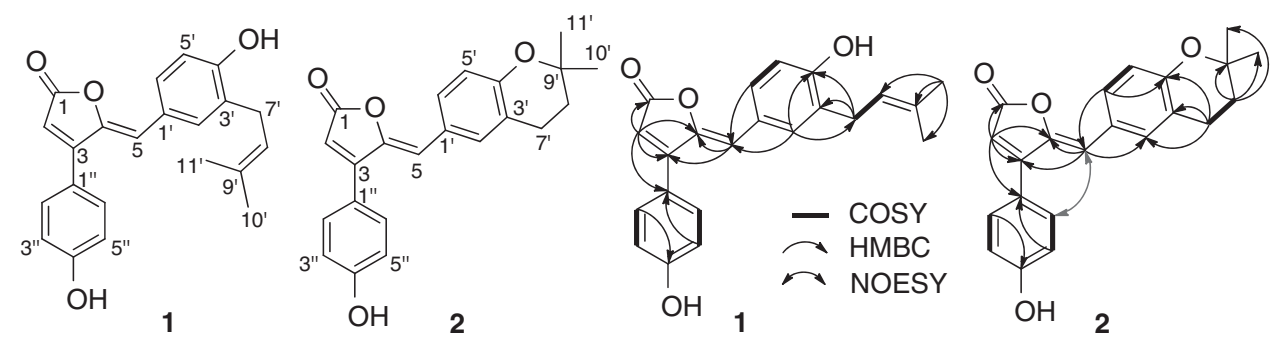

Figure 1 Structures of compounds 1 and 2 and key HMBC, NOESY and COSY correlations of 1 and 2. A full color version of this figure is available at The Journal of Antibiotics journal online.

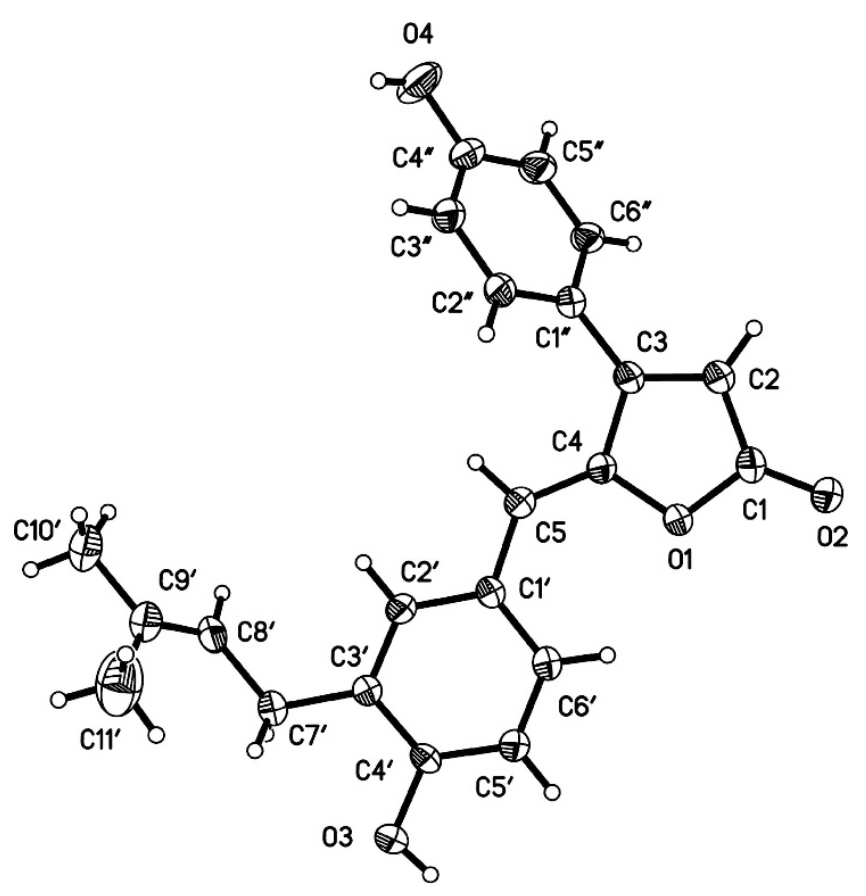

Figure 2 ORTEP drawing of the crystal structure of 1.

evaporation of seawater collected in Laizhou Bay (Weifang Haisheng Chemical Factory, Weifang, China).

\section{Strain}

The fungal strain A. terreus OUCMDZ-1925 was isolated from the viscera of C. haematocheilus grown in the waters of the Yellow River Delta, and identified by BLAST search of ITS sequence using the GenBank database. ITS sequence of OUCMDZ-1925 strain (GenBank accession no GQ812053) showed 100\% of homology with those of A. terreus (GenBank accession number KC762934 and KC582297). ${ }^{12}$ The voucher specimen was stored in our laboratory at $-80^{\circ} \mathrm{C}$. The working strain was prepared on potato dextrose agar slants and stored at $4{ }^{\circ} \mathrm{C}$.

\section{Fermentation}

Spores were directly inoculated into $1000 \mathrm{~mL}$ conical flasks containing $300 \mathrm{ml}$ liquid medium (glucose $10 \mathrm{~g}$, maltose $20 \mathrm{~g}$, mannitol $20 \mathrm{~g}$, monosodium glutamate $10 \mathrm{~g}, \mathrm{CaCO}_{3} 20 \mathrm{~g}, \mathrm{KH}_{2} \mathrm{PO}_{4} 0.5 \mathrm{~g}, \mathrm{MgSO}_{4} \cdot 7 \mathrm{H}_{2} \mathrm{O} 0.3 \mathrm{~g}$, corn steep liquor $1 \mathrm{~g}$, yeast extract $3 \mathrm{~g}$ and sea salt $33 \mathrm{~g}$, dissolved in $11 \mathrm{of}$ tap water, $\mathrm{pH}$ 7.5). The fungus $A$. terreus OUCMDZ-1925 was grown under static conditions at $30^{\circ} \mathrm{C}$ for 45 days in 35 conical flasks.
Extraction and isolation

The whole fermentation broth $(10.5 \mathrm{l})$ was filtered through a cheesecloth to separate the filtrate from the mycelia. The filtrate was extracted three times with an equivalent volume of EtOAc to give an EtOAc solution, as the mycelia were extracted three times with acetone. The acetone solution was concentrated in vacuum to afford an aqueous solution. The aqueous solution was extracted three times with an equivalent volume of EtOAc to give another EtOAc solution. Both EtOAc solutions were combined and concentrated in vacuum to give a crude gum $(35 \mathrm{~g})$.

The crude extract was separated into eight fractions on a silica gel VLC column using a stepwise gradient elution, with $\mathrm{CH}_{2} \mathrm{Cl}_{2}$ /petroleum ether (50$100 \%)$ followed by $\mathrm{MeOH} / \mathrm{CH}_{2} \mathrm{Cl}_{2}(0-50 \%)$. Fraction $4(1 \mathrm{~g})$ was separated into four subfractions (Fr.4-1-Fr.4-4) on Sephadex LH-20, eluting with $\mathrm{MeOH}$. Fraction 4-3 (150 mg) was further separated into four subfractions (Fr.4-3-1-Fr.4-3-4) by VLC on RP-18 silica using a stepwise gradient elution with $5-90 \% \mathrm{MeOH} / \mathrm{H}_{2} \mathrm{O}$. Fraction 4-3-1 (45 mg) was finally purified by the semi-preparative HPLC $\left(60 \% \mathrm{MeOH} / \mathrm{H}_{2} \mathrm{O}\right)$ to yield $1\left(20 \mathrm{mg}, t_{\mathrm{R}} 77 \mathrm{~min}\right)$. Fraction 5 (2.1 g) was separated into four subfractions (Fr.5-1-Fr.5-4) by VLC on RP-18 silica using a stepwise gradient elution with $5-90 \% \mathrm{MeOH} / \mathrm{H}_{2} \mathrm{O}$. Fraction 5-2 $(450 \mathrm{mg})$ was further separated into four subfractions (Fr.5-2-1Fr.5-2-4) on Sephadex LH-20, eluting with $\mathrm{MeOH}$. Fraction 5-2-3 (80 mg) was finally purified by the semi-preparative $\mathrm{HPLC}\left(70 \% \mathrm{MeOH} / \mathrm{H}_{2} \mathrm{O}\right)$ to yield 2 (23 mg, $\left.t_{\mathrm{R}} 31 \mathrm{~min}\right)$.

\section{$\mathrm{X}$-ray structure determination of 1}

Compound 1 was obtained as a colorless triclinic crystal with molecular formula $\mathrm{C}_{22} \mathrm{H}_{20} \mathrm{O}_{4}$. Space group $P-1, a=9.7055(8) \AA, b=13.3599(12) \AA$, $c=14.3396(13) \quad \AA, \quad \alpha=85.5280(10), \quad \beta=90.324(2), \quad \gamma=90.216(2)$, $V=1853.6(3) \AA^{3}, Z=2, D_{\text {calcd }}=1.281 \mathrm{mg} \mathrm{m}^{-1}, \mu=0.089 \mathrm{~mm}^{-1}, F(000)=756$, crystal size $0.40 \times 0.17 \times 0.15 \mathrm{~mm}, T=298(2) \mathrm{K}$. A total of 6463 unique reflections $\left(2 \theta<50^{\circ}\right)$ were collected on a CCD area detector diffractometer with graphite monochromated MoK $\alpha$ radiation $(\lambda=0.71073 \AA)$. The structure was solved by direct methods (SHELXS-97) and expanded using Fourier techniques (SHELXL-97). The final cycle of full-matrix least squares refinement was based on 6463 unique reflections $\left(2 \theta<50^{\circ}\right)$ and 2865 variable parameters and converged with unweighted and weighted agreement factors of $R_{1}=0.1416, R_{\mathrm{w}}=0.1447$ and $R=0.0685$ for $I>2 \operatorname{sigma}(I)$ data. Crystallographic data (excluding structure factors) for structure $\mathbf{1}$ in this paper have been deposited with the Cambridge Crystallographic Data Centre as supplementary publication number CCDC 946389. Copies of the data can be obtained, free of charge, on application to CCDC, 12 Union Road, Cambridge CB2 1EZ, UK (fax: + 44 (0)-1223-336033 or e-mail: deposit@ccdc.cam.ac.uk).

\section{Anti-influenza A virus (H1N1) bioassay}

The antiviral activity against H1N1 was evaluated by the CPE inhibition assay. ${ }^{18,19}$ Confluent MDCK cell monolayers were firstly incubated with influenza virus (A/Puerto Rico/8/34 (H1N1), PR/8) at $37^{\circ} \mathrm{C}$ for $1 \mathrm{~h}$. After removing the virus dilution, cells were maintained in an infecting media (RPMI $1640,4 \mu \mathrm{g} \mathrm{ml}^{-1}$ of trypsin) containing different concentrations of test compounds at $37^{\circ} \mathrm{C}$. After $48 \mathrm{~h}$ incubation at $37^{\circ} \mathrm{C}$, the cells were fixed with $100 \mu \mathrm{l}$ of $4 \%$ formaldehyde for $20 \mathrm{~min}$ at room temperature. After removal of 
the formaldehyde, the cells were stained with $0.1 \%$ crystal violet for $30 \mathrm{~min}$. The plates were washed and dried, and the intensity of crystal violet staining for each well was measured in a microplate reader (Bio-Rad, USA) at $570 \mathrm{~nm}$. The $\mathrm{IC}_{50}$ was calculated as the compound concentration required for inhibiting influenza virus yield at $48 \mathrm{~h}$ post infection by $50 \%$. Ribavirin was used as the positive control with the $\mathrm{IC}_{50}$ values of $118.8 \mu \mathrm{m}$.

\section{Cytotoxicity assay}

Cytotoxicity was assayed by the MTT ${ }^{20}$ and SRB methods, ${ }^{21}$ respectively. In the MTT assay, K562, A549 and HL-60 cell lines were cultured in RPMI-1640 supplemented with $10 \%$ FBS under a humidified atmosphere of $5 \% \mathrm{CO}_{2}$ and $95 \%$ air at $37^{\circ} \mathrm{C}$. Cell suspensions $(198 \mu \mathrm{l})$ at a density of $5 \times 10^{4} \mathrm{cells} \cdot \mathrm{ml}^{-1}$ were plated in 96-well microtiter plates and incubated for $24 \mathrm{~h}$. Then, the test solutions $(2 \mu \mathrm{l}$ in DMSO) were added to each well and further incubated for $72 \mathrm{~h}$. The MTT solution $\left(20 \mu \mathrm{l}, 5 \mathrm{mg} \mathrm{ml}^{-1}\right.$ in IPMI-1640 medium) was then added to each well and incubated for $4 \mathrm{~h}$. The old medium containing MTT $(150 \mu \mathrm{l})$ was then gently replaced by DMSO and pipetted to dissolve any formazan crystals formed. Absorbance was then determined on a Spectra Max Plus plate reader at $570 \mathrm{~nm}$. In the SRB assay, the Hela and HCT-116 cell suspension $(200 \mu \mathrm{l})$ was plated in 96 -well plates at density of $2 \times 10^{5}$ cell per $\mathrm{ml}$. Then, the test solutions $(2 \mu \mathrm{l}$ in $\mathrm{MeOH})$ were added to each well and the culture was further incubated for $24 \mathrm{~h}$. The cells were fixed with $12 \%$ trichloroacetic acid and the cell layer stained with $0.4 \%$ SRB. The absorbance of the SRB solution was measured at $515 \mathrm{~nm}$. Adriamycin was used as the positive control with $\mathrm{IC}_{50}$ values of $0.64,0.16,0.65,0.60$ and $0.21 \mu \mathrm{M}$ for $\mathrm{K} 562$, A549, HL-60, Hela and HCT-116 cell lines, respectively.

\section{DPPH scavenging assay}

The test sample solution $(160 \mu \mathrm{l}$ in $\mathrm{MeOH})$ and $\mathrm{DPPH}$ solution $(40 \mu \mathrm{l}$ in $\mathrm{MeOH}$ ) were plated in 96 cell plates and incubated in the dark for $30 \mathrm{~min}^{22-24}$ Then, absorbance was measured at $520 \mathrm{~nm}$ and the inhibition was calculated. $\mathrm{IC}_{50}$ values were calculated from the log-dose inhibition curve as the concentration of sample required to scavenge $50 \%$ of DPPH free radicals Ascorbic acid was used as the positive control with an $\mathrm{IC}_{50}$ value of $1.7 \mu \mathrm{M}$.

\section{ABTS decolorization assay}

The ABTS radical cation (ABTS ${ }^{+}$) was first produced by reacting ABTS stock solution $(7 \mathrm{mM})$ with $2.45 \mathrm{~mm}$ potassium persulfate. ${ }^{25-27}$ The mixture was then placed in the dark at room temperature overnight before use. The reaction mixture consisted of $200 \mu \mathrm{l}$ of sample or positive controls and $6 \mathrm{ml}$ of ABTS + working solution was vortexed for $30 \mathrm{~s}$. The absorbance was read at $734 \mathrm{~nm}$ after reaction for $4 \mathrm{~min}$ at $30^{\circ} \mathrm{C}$. The antioxidant activities of the test compounds were expressed as $\mathrm{IC}_{50}$ that was defined as the concentration to inhibit the formation of ABTS radicals by $50 \%$. All determinations were performed in triplicate. Trolox and ascorbic acid were used as the positive controls with $\mathrm{IC}_{50}$ values of $2.04 \mathrm{~mm}$ and $2.85 \mathrm{~mm}$, respectively.

\section{ACKNOWLEDGEMENTS}

This work was supported by grants from the NSFC (Nos 21172204 \& 41376148, 31071586), 973 Program of China (No. 2010CB833804), 863 Program of China (Nos 2012AA092104 \& 2013AA092901), Special Fund for Marine Scientific Research in the Public Interest of China (No. 2010418022-3 and from the Shandong Natural Science Foundation (No. ZR2009CQ030).
1 Bugni, T. S. \& Ireland, C. M. Marine-derived fungi: a chemically and biologically diverse group of microorganisms. Nat. Prod. Rep. 21, 143-163 (2004).

2 Saleem, M. et al. Marine natural products of fungal origin. Nat. Prod. Rep. 24 1142-1152 (2007)

3 Parvatkar, R. R., D'Souza, C., Tripathi, A. \& Naik, C. G. Aspernolides A and B, butenolides from a marine-derived fungus Aspergillus terreus. Phytochemistry 70, 128-132 (2009).

4 Tale, N. P., Shelke, A. V., Tiwari, G. B., Thorat, P. B. \& Karade, N. N. New concise and efficient synthesis of rubrolides $\mathrm{C}$ and $\mathrm{E}$ via intramolecular Wittig reaction. Helv. Chim. Acta 95, 852-857 (2012).

5 Miao, S. \& Andersen, R. J. Rubrolides A-H, metabolites of the colonial tunicate Ritterella rubra. J. Org. Chem. 56, 6275-6280 (1991).

6 Wang, W., Kim, H., Nam, S.-J., Rho, B. J. \& Kang, H. Antibacterial butenolides from the Korean tunicate Pseudodistoma antinboja. J. Nat. Prod. 75, 2049-2054 (2012)

7 Ortega, M. J., Zubía, E., Ocaña, J. M., Naranjo, S. \& Salvá, J. New rubrolides from the Ascidian Synoicum blochmanni. Tetrahedron 56, 3963-3967 (2000).

8 Pearce, A. N. et al. E/Z-Rubrolide 0, an anti-inflammatory halogenated furanone from the New Zealand ascidian Synoicum n. sp. J. Nat. Prod. 70, 111-113 (2007).

9 Sikorska, J. et al. Antimicrobial rubrolides from a South African species of synoicum tunicate. J. Nat. Prod. 75, 1824-1827 (2012).

10 Manzanaro, S., Salvá, J. \& de la Fuente, J. Á. Phenolic marine natural products as aldose reductase inhibitors. J. Nat. Prod. 69, 1485-1487 (2006).

11 Boukouvalas, J. \& McCann, L. C. Synthesis of the human aldose reductase inhibitor rubrolide L. Tetrahedron Lett. 51, 4636-4639 (2010).

12 Chen, Z.-Q., Liu, P.-P., Wang, Y. \& Zhu, W.-M. The antibacterial polyketides of Aspergillus terreus OUCMDZ-1925 from Yellow River delta. Mycosystema 32, 277-285 (2013).

13 Wang, H. et al. A new cytotoxic indole-3-ethenamide from the halotolerant fungus Aspergillus sclerotiorum PT06-1. J. Antibiot. 64, 679-681 (2011).

14 Fan, Y. et al. Indole-diterpenoids with anti-H1N1activity from the aciduric fungus Penicillium camemberti OUCMDZ-1492. J. Nat. Prod. 76, 1328-1336 (2013).

15 Wang, J. et al. Cytotoxic polyphenols from the fungus Penicillium expansum 091006 endogenous with mangrove plant Excoecaria agallocha. Planta Med. 78, 1861-1866 (2012).

16 Wang, Y., Lu, Z., Sun, K. \& Zhu, W. Effects of high salt stress on secondary metabolite production in the marine-derived fungus Spicaria elegans. Mar. Drugs 9, 535-542 (2011).

17 Zhuang, Y. et al. New quinazolinone alkaloids within rare amino acid residue from coral-associated fungus, Aspergillus versicolor LCJ-5-4. Org. Lett. 13, 1130-1133 (2011).

18 Grassauer, A. et al. lota-carrageenan is a potent inhibitor of rhinovirus infection. Virol. J. 5, 107 (2008).

19 Hung, H.-C. et al. Aurintricarboxylic acid inhibits influenza virus neuraminidase. Antiviral Res. 81, 123-131 (2009).

20 Mosmann, T. Rapid colorimetric assay for cellular growth and survival: application to proliferation and cytotoxicity assays. Immunol. Methods 65, 55-63 (1983).

21 Skehan, P. et al. New colorimetric cytotoxicity assay for anticancer-drug screening. J. Natl Cancer Inst. 82, 1107-1112 (1990).

22 Chen, C.-W. \& Ho, C.-T. Antioxidant properties of polyphenols extracted from green and black teas. J. Food Lipids 2, 35-46 (1995).

23 Chen, Y., Wang, M., Rosen, R. T. \& Ho, C.-T. 2,2-Diphenyl-1-picrylhydrazyl radicalscavenging active components from Polygonum multiflorum Thunb. J. Agric. Food Chem. 47, 2226-2228 (1999).

24 Wang, W. et al. Cerebrosides of the halotolerant fungus Alternaria raphani isolated from a sea salt field. J. Nat. Prod. 72, 1695-1698 (2009).

25 Miller, N. J., Rice-Evans, C., Davies, M. J., Gopinathan, V. \& Milner, A. A novel method for measuring antioxidant capacity and its application to monitoring the antioxidant status in premature neonates. Clin. Sci. 84, 407-412 (1993).

$26 \mathrm{Re}, \mathrm{R}$. et al. Antioxidant activity applying an improved ABTS radical cation decolorization assay. Free Radical Biol. Med. 26, 1231-1237 (1999).

27 Reddy, S. V., Tiwari, A. K., Kumar, U. S., Rao, R. J. \& Rao, J. M. Free radical scavenging, enzyme inhibitory constituents from antidiabetic ayurvedic medicinal plant Hydnocarpus wightiana Blume. Phytother. Res. 19, 277-281 (2005).

28 Kar, A. \& Argade, N. P. A facile synthesis of rubrolide E. Synthesis (Mass) 14 2284-2286 (2005)

Supplementary Information accompanies the paper on The Journal of Antibiotics website (http://www.nature.com/ja) 